\title{
Use of Nucleic-Acid Homologies in the Taxonomy of Anaerobic Bacteria
}

\author{
JOHN L. JOHNSON \\ Virginia Polytechnic Institute and State University, Blacksburg, Virginia 24061
}

\begin{abstract}
Nucleic acid homology studies are providing a common base for establishing bacterial groups. Few phenotypic characteristics have consistently correlated with homology data among the various groups of organisms that we have investigated. However, there are correlations that are specific for a given group of bacteria such that nucleic-acid homology data can be used to select those phenotypic properties that will be most useful for identification and taxonomic purposes.
\end{abstract}

It has been almost 10 years since deoxyribonucleic acid (DNA) reassociation, or homology, experiments were first applied to problems of bacterial taxonomy. Since then, these experiments have been directed primarily at elucidating nucleotide sequence similarities among organisms whose designations were based on an existing taxonomic structure. The results of these homology studies have, therefore, usually been used by the investigators as a measure of homogeneity or heterogeneity within phenoty pically defined groups. In the investigations I wish to discuss here (presented at the Annual Meeting of the American Society for Microbiology, 1973), on the other hand, the primary groupings have been based much on the homology results, and the general aim has been to determine which phenoty pic characters correlate best with the groups so defined.

The technique that we employ most extensively in our laboratory is the membrane filter competition experiment. In this procedure, unlabeled DNA fragments compete with tritium-labeled DNA fragments for reassociation sites on strands of unlabeled DNA immobilized on a membrane filter. This procedure measures that fraction of a reference organism's genome which can react with competitor DNA from various other organisms (Fig. 1).

We routinely incubate the reaction mixture at a temperature $25 \mathrm{C}$ below the thermal melting temperature $\left(T_{m}\right)$ of the reference DNA (as measured in standard saline citrate [ $1 \times \mathrm{SSC}]: 0.15 \mathrm{M} \mathrm{NaCl}-0.015 \mathrm{M}$ sodium citrate, $\mathrm{pH}$ 7). Under these conditions, the maximal binding (i.e., binding when no competitor DNA is present) is usually about $40 \%$ although it ranges from 25 to $50 \%$. The actual amount of binding depends on the incubation temperature and on the quality of both the labeled DNA and the DNA on the filter. The maximal binding has been normalized to $100 \%$ in the figure for ease of comparison. The extent of homologous competition at the two most commonly used levels, i.e., 75 and $150 \mu \mathrm{g}$ of competitor DNA, is in the ranges of 86 to $89 \%$ and 90 to $93 \%$, respectively. If the homologous competition is much less than this, there is nonspecific binding in the system. Also, in a competition experiment the effect of the competitor DNA is exponential. Therefore, these experiments are very sensitive to impure DNA preparations such as might result from mixed cultures.

As the fraction of the genome which can react diminishes, the thermal stability of the heterologous duplexes that are formed decreases $(3,9,11,13)$. Figure 2 depicts the homologous and heterologous thermal-stability profiles of Propionibacterium acnes and $P$. avidum, which show about 53\% homology with each other (8). The temperature difference between homologous and heterologous duplexes at which $50 \%$ of the duplexes have disassociated, $\mathrm{T}_{\mathrm{m}}$ (e), is $12.5 \mathrm{C}$. Thus, the experiment was able to resolve a 3\% guanine + cytosine $(G+C)$ difference for both the homologous and heterologous profiles.

Listed in Table 1 are homology and $T_{m}$ (e) values from organisms representing diverse groups; the percent $\mathrm{G}+\mathrm{C}$ of the DNA preparations ranges from 28 to $70 \% \mathrm{G}+\mathrm{C}$. The data are represented graphically in Fig. 3. In general, the correlation between the percent homology and the decreased thermal stability of heterologous duplexes is quite good. There may, 


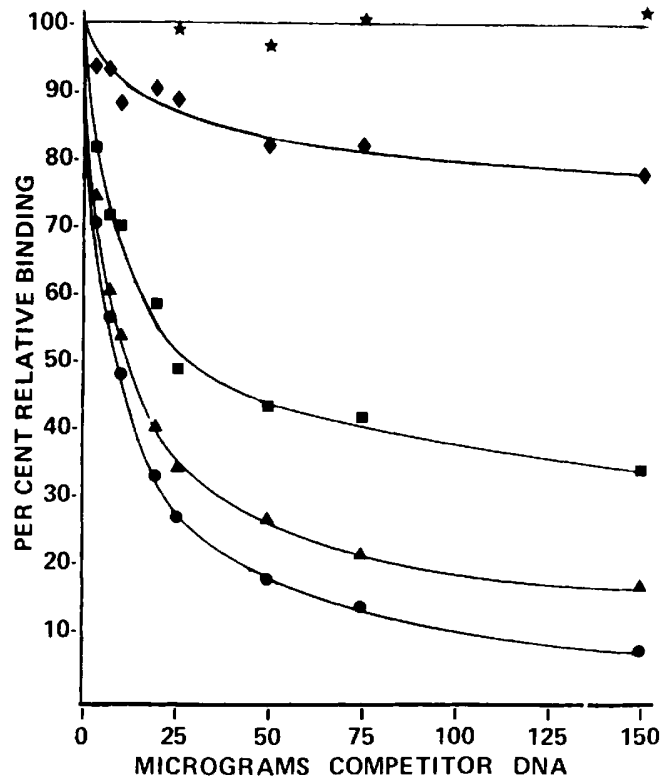

FIG. 1. Competition profiles using various Bacte. roides DNA preparations. The reactions were carried out in $2 \times S S C$ and at $61.5 \mathrm{C} / T_{m}(1 \times S S C)-25 \mathrm{C} /$. Symbol: $\bullet$, homologous competitor DNA.

however, be a small degree of difference in some groups; for example, the duplexes of DNA from lactobacilli with low homology may be somewhat less stable than those of the majority of the organisms in that homology range. Anderson and Ordal's data (1) on marine vibrios (Fig. 3) are similar to those for the lactobacilli. In a case where the percent $\mathrm{G}+\mathrm{C}$ content of the DNA from organisms is not the same, the decrease in thermal stability is accentuated. For example, $P$. acnes $(59 \% \mathrm{G}+$ C) and $P$. avidum $(62 \% \mathrm{G}+\mathrm{C})$ show $53 \%$ homology with each other, as do $P$. jensenii $(66 \% \mathrm{G}+\mathrm{C})$ and $P$. thoenii $(66 \% \mathrm{G}+\mathrm{C})$. However, the heterologous DNA duplexes from $P$. acnes- $P$. avidum are 5 to $6 \mathrm{C}$ less stable than the $P$. jensenii-P. thoenii duplexes (Table 1, Fig. $3)$. In other cases, for example Bacteroides and Fusobacterium, the variations in the thermal stability of heterologous duplexes cannot be explained on the basis of percent $\mathrm{G}+\mathrm{C}$. Another point of interest in Fig. 3 is that, for the heterologous duplexes that show high homology $(80$ to $100 \%)$, the homology values usually drop more rapidly than do the $T_{m}$ (e) values. This indicates that in this homology range the major variations that are being measured are differences in genome size and alteration in the linear arrangement of cistrons due to such mechanisms as conjugation, trans- formation, or transduction. At about $70 \%$ homology, there appears to be a distinct break. In the lower homology range, differences in the base sequences become increasingly important, as indicated by the decreasing thermal stabilities, although some of the scatter may be the results of the above-mentioned mechanisms. Therefore, if one were to determine a curve by using all of the coordinates in Fig. 3, a diauxic curve would result.

How should DNA homology values be used in taxonomy? If they are regarded as an end in themselves, they soon become boring and lifeless sets of figures without much practical use. What I believe to be the most useful and interesting questions to ask are as follows. "How do the biological properties which have traditionally been used to identify and classify bacteria correlate with DNA homology values?" "Do certain phenotypic characters tend to be more conserved than others, and are they thus more useful for classification and identification?"

The data in Table 2 exemplify a case where two groups of clostridia could not readily be differentiated by phenotypic tests but could be clearly distinguished by DNA/DNA homology experiments. The homology values were 70 to $100 \%$ within each group, but only 20 to $40 \%$ between groups. We have called the two gruups Clostridium butyricum and $C$. beijerinckii. One

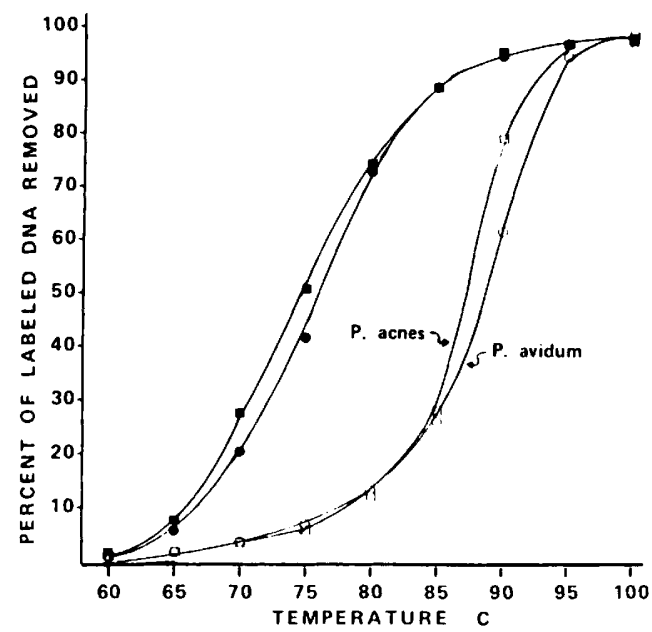

FIG. 2. Thermal-stability profiles of homologous and heterologous duplexes of Propionibacterium acnes and $P$. avidum (P. acnes ${ }^{3} H-D N A$ : $\square$, homologous; $\square$, heterologous; $P$. avidum ${ }^{3} H-D N A$ : $\circ$, homologous; $\bullet$, heterologous). The reassociations were carried out in 2 $\times$ SSC and at $68.5 \mathrm{C}$ (P. acnes ${ }^{3} \mathrm{H}$-fragments) and at $69.5 C$ (P. avidum ${ }^{3} \mathrm{H}$-fragments). The elution profiles were carried out in $0.5 \times \operatorname{SSC}(1,7)$. 
TABLE 1. Homology and $\Delta T^{m}(e)$ values for DNA preparations depicted in Fig. 3

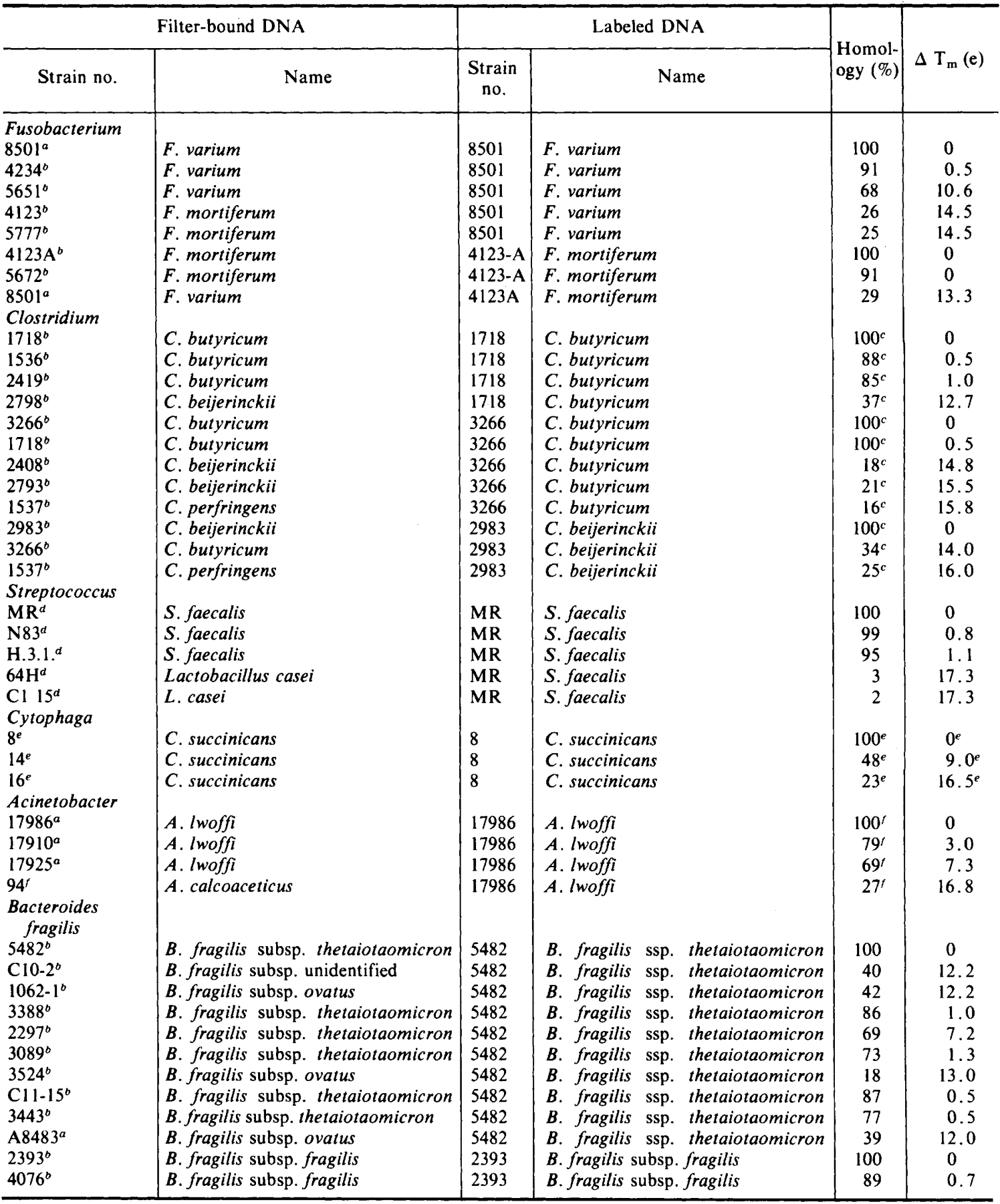

${ }^{a}$ ATCC identification numbers.

${ }^{b}$ VPI identification numbers.

${ }^{e}$ Homology values in reference 4.

${ }^{d}$ Strains received from Morrison Rogosa.

${ }^{e}$ Strain identification numbers and homology values in reference 9 .

${ }^{f}$ Strain identification numbers and homology values in reference 7.

s Strain identification numbers and homology values in reference 8 . 
TABLE 1-Continued

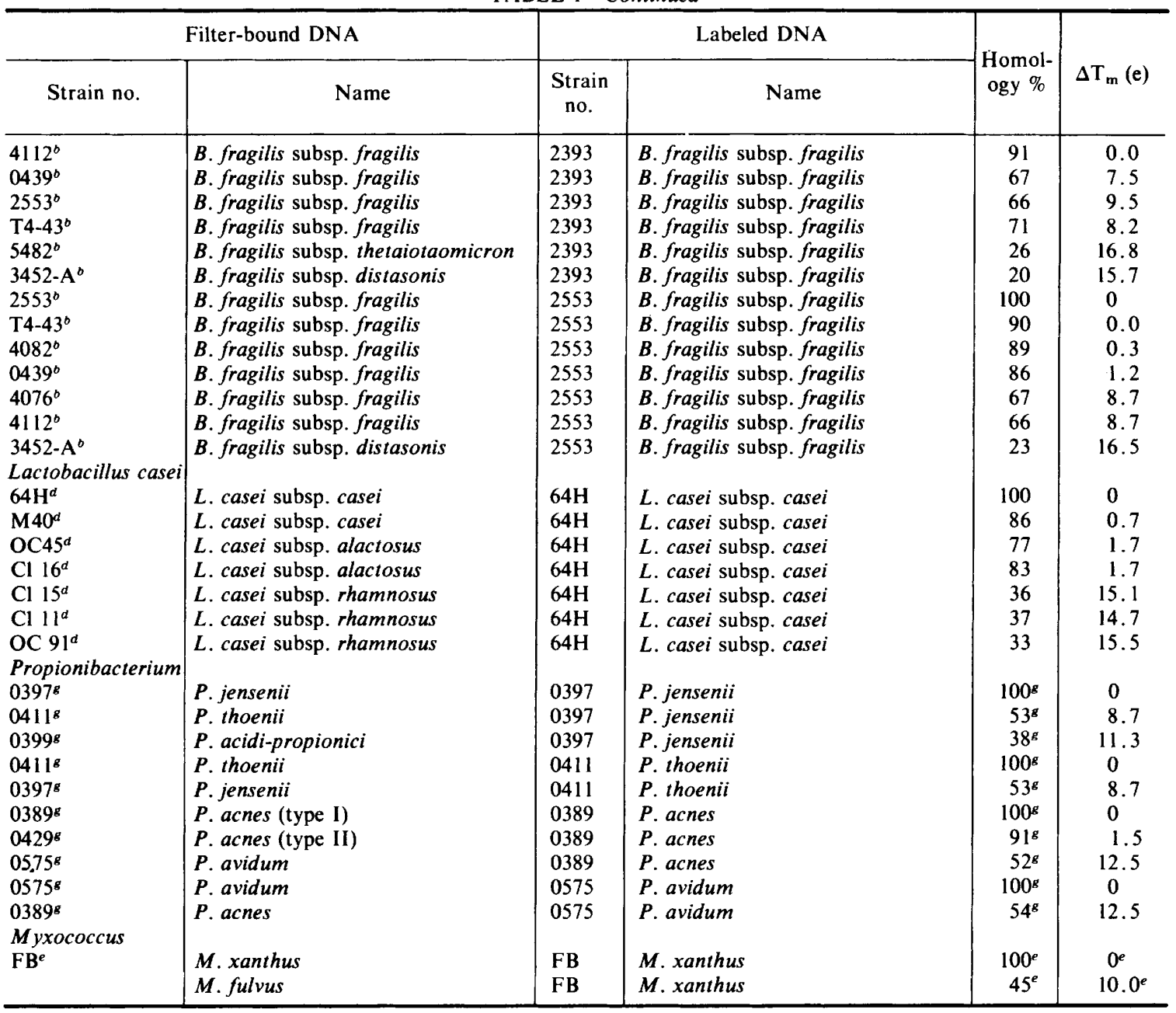

major difference between them is that $C$. butyricum strains will grow on a glucose-mineral salts medium containing only biotin as an additional growth factor, whereas the $C$. beijerinckii strains have more complex growth requirements (4). Therefore, the usual method of using a complex basal medium for fermentation tests tended to mask fundamental differences that were indicated by the homology results. Also, the cell walls of the $C$. butyricum strains contain only glucose, and the walls of $C$. beijerinckii contain glucose and galactose. Two of the $C$. fallax strains (Table 2) do not belong to either the $C$. butyricum or the $C$. beijerinckii homology group. They show little, if any, DNA homology with either species (4) and appear to ferment fewer sugars and have different cell wall structure from the above groups $(4,6)$.

The propionibacteria provide some unique correlations between phenotypic characteristics and DNA homology results. The anaerobic corynebacteria were subdivided into 11 species by the use of conventional tests (16). Although this degree of speciation was not supported by most workers $(14,18,21,22)$, there was disagreement on what should be considered valid species. A homology study on 80 strains resulted in the definition of three major groups, which we have designated $P$. acnes, $P$. avidum, and $P$. granulosum (8). P. acnes was the largest group, with 62 strains, and is the most homogeneous with which we have worked. The average homologies with the reference strains were $90 \%$ and above (8). However, there were two distinct types within $P$. acnes, based on the sugar composition of the cell walls. The walls of type I $P$. acnes contain galactose, glucose, and mannose, and those of type II contain only glucose and mannose (8). The strains in the $P$. avidum group also show two patterns of cell 
wall sugars (galactose, glucose, and mannose; and glucose and mannose), which correspond to those in the $P$. acnes group. It is also of interest that, although most strains of $P$. acnes and $P$. avidum contain the L-isomer of $\alpha, \epsilon$-diaminopimelic acid (L-DAP), occasional strains in both species having the type II cell wall sugar composition (glucose, mannose) contain mesoDAP (8). Unabsorbed serum for $P$. acnes type II agglutinates cell walls of $P$. avidum type II to a greater extent than those of $P$. acnes type I (C. $\mathrm{S}$. Cummins, personal communication; Table 3 ). Therefore, the cell wall structure appears to be conserved between these two groups of organisms.

Thirty sugars and polyols are routinely used at the Anaerobe Laboratory (Virginia Polytech-

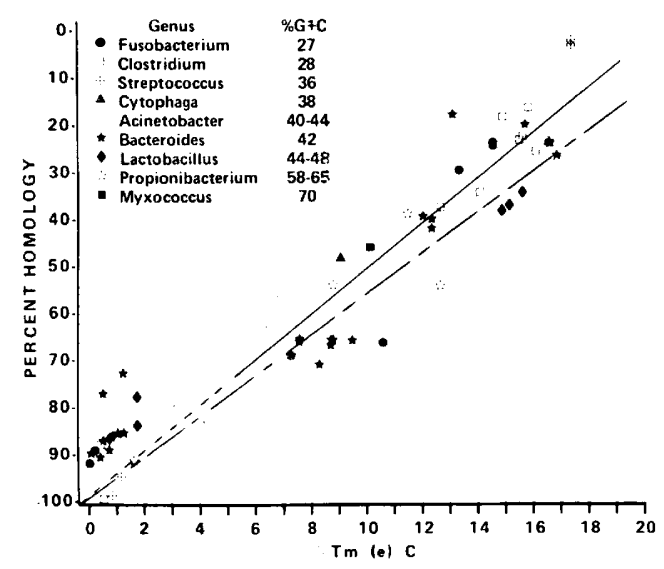

FIG. 3. Plot of percent homology values versus the degrees $C \Delta T_{m}(e)$. Solid line, the estimated best-fit line using the lower homology and the homologous [100\% homology, 0.0 C $\Delta T_{m}$ (e)] values. Slope of the line is $5 \%$ homology per degree $C \Delta T_{m}(e)$. Thermal stabilities of the high-homology range heterologous duplexes (dashed part of line) were not considered when estimating the curve as discussed in the text. The results of Anderson and Ordal (1) using marine vibrio DNA preparations $(\rightarrow-\rightarrow-$ ). nic Institute and State University, Blacksburg) for identification, and $80 \%$ of these carbohydrates are utilized to the same extent by organisms in the three homology groups (6). With respect to the remaining six sugars, $P$. avidum strains are more similar to those of $P$. granulosum than to those of $P$. acnes (6).

The arrangement of the classical propionibacteria in the 7th edition of Bergey's Manual (2) is based primarily on C. B. van Niel's investigation of these organisms in 1928 (19). Many of the same strains were used by us to generate the homology data summarized in Table 4 (8). It is of interest to note that van Niel used morphological and sugar-utilization characteristics to establish the major groups, and the species designations within these groups were based primarily on sugar-utilization differences. The DNA homology data correlate extremely well with van Niel's major groups, but we were unable to distinguish between the species within each group.

Recently, we have been working on the Bacteroides fragilis group of organisms. At present, these are subdivided into five subspecies on the basis of indole production and the differential utilization of seven to eight carbohydrates. The utilization patterns for 20 other carbohydrates and polyols are identical among these strains, and morphological differences are negligible (6). To date, we have delineated 10 homology groups (strains having 80 to $100 \%$ homology to the reference strain) from this group of organisms. The interhomology values for the reference strains are shown in Table 5. The two homology groups of $B$. fragilis subsp. fragilis are closely related, and we have not been able to distinguish them from each other phenotypically. Reference strains of the two homology groups in B. fragilis subsp. distasonis have negligible homology with each other. These groups do differ in the utilization of two carbohydrates, but only a very limited number of strains has been investigated so far.

TABLE 2.DNA similarities of some butyric-acid producing clostridia

\begin{tabular}{l|c|c|c}
\hline \multirow{2}{*}{\multicolumn{1}{c|}{}} & & \multicolumn{2}{c}{$\begin{array}{c}\text { No. of strains with } \\
70 \text { to 100\% homology to }\end{array}$} \\
\cline { 2 - 4 } \multicolumn{1}{c}{ Designated as } & No. of strains & $\begin{array}{c}\text { C. butyricum } \\
3266\end{array}$ & $\begin{array}{c}\text { C. beijerinckii } \\
2983\end{array}$ \\
\hline C. butyricum & 20 & 10 & 10 \\
C. multifermentans & 7 & 5 & 2 \\
C. fallax & 5 & 3 & 2 \\
C. beijerinckii & 2 & 0 & 2 \\
C. lacto-acetophilum & 2 & 0 & 2 \\
\hline
\end{tabular}


TABLE 3. Relationships between cell wall sugars, serological reactions, and percent homologies among propionibacteria

\begin{tabular}{|c|c|c|c|c|c|c|}
\hline \multirow[b]{2}{*}{ Organism } & \multirow[b]{2}{*}{$\begin{array}{l}\text { Cell wall } \\
\text { sugars }\end{array}$} & \multicolumn{3}{|c|}{ Percent homology } & \multicolumn{2}{|c|}{ Titer unabsorbed serum } \\
\hline & & $\begin{array}{c}\text { P. acnes } \\
\text { I }\end{array}$ & $\begin{array}{c}P . \text { acnes } \\
\text { II }\end{array}$ & $\begin{array}{c}\text { P. avidum } \\
\text { I }\end{array}$ & $\begin{array}{c}\text { P. acnes } \\
\text { I }\end{array}$ & $\begin{array}{c}\text { P. acnes } \\
\text { II }\end{array}$ \\
\hline P. acnes I & $\begin{array}{l}\text { Glu, Gal, } \\
\text { Mann }\end{array}$ & 97 & 97 & 51 & 320 & 80 \\
\hline P. acnes II & Glu, Gal & 90 & 94 & 52 & 160 & 640 \\
\hline P. avidum I & $\begin{array}{l}\text { Glu, Gal, } \\
\text { Mann }\end{array}$ & 53 & 52 & 95 & 80 & 0 \\
\hline P. avidum II & Glu, Gal & 43 & 52 & 84 & 80 & 320 \\
\hline P. granulosum & $\begin{array}{l}\text { Glu, (tr) } \\
\text { Gal, Mann }\end{array}$ & 15 & 17 & 15 & 0 & 0 \\
\hline
\end{tabular}

TABLE 4. Comparison between van Niel's classification and homology groups

\begin{tabular}{|c|c|c|c|c|c|}
\hline \multirow[b]{2}{*}{$\begin{array}{l}\text { van Niel's classification } \\
\text { (Bergey's Manual, 7th ed.) }\end{array}$} & \multirow[b]{2}{*}{$\begin{array}{l}\text { Provisional name } \\
\text { of homology group }\end{array}$} & \multicolumn{4}{|c|}{$\begin{array}{l}\text { Percent homology to reference } \\
\text { DNA from }\end{array}$} \\
\hline & & $\begin{array}{l}P . \text { fre- } \\
\text { uden- } \\
\text { reichii } \\
0407\end{array}$ & $\begin{array}{c}\text { P. tho- } \\
\text { enii } \\
0411\end{array}$ & $\begin{array}{c}\text { P. jen- } \\
\text { senii } \\
0397\end{array}$ & $\begin{array}{l}\text { P. acidi- } \\
\text { propi- } \\
\text { onici } \\
0399\end{array}$ \\
\hline $\begin{array}{l}\text { Group I } \\
P . \text { freudenreichii } \\
P . \text { shermanii }\end{array}$ & P. freudenreichii & 90 & 20 & 26 & 25 \\
\hline $\begin{array}{l}\text { Group II, A } \\
\text { (i) } P . \text { rubrum } \\
P . \text { thoenii } \\
\text { (ii) } P . \text { zeae } \\
P . \text { technicum } \\
P . \text { raffinosaceum } \\
P . \text { peterssonii } \\
P . \text { jensenii }\end{array}$ & $\begin{array}{l}P . \text { thoenii } \\
P . \text { jensenii }\end{array}$ & $\begin{array}{l}12 \\
17\end{array}$ & $\begin{array}{l}96 \\
51\end{array}$ & $\begin{array}{l}53 \\
88\end{array}$ & $\begin{array}{l}30 \\
30\end{array}$ \\
\hline $\begin{array}{l}\text { Group II, B } \\
P . \text { arabinosum } \\
P . \text { pentosaceum }\end{array}$ & P. acidi-propionici & 8 & 35 & 38 & 87 \\
\hline
\end{tabular}

The $B$. fragilis subsp, thetaiotaomicron homology groups again have identical substrate-utilization patterns. A point of interest is that DNA from organisms in group 1 contains 46 to $47 \%$ $\mathrm{G}+\mathrm{C}$, whereas DNA from organisms in groups 2 and 3 contain 41 to $42 \% \mathrm{G}+\mathrm{C}$. The $B$. fragilis subsp. ovatus homology groups have about $60 \%$ homology with each other and about $40 \%$ with groups 2 and 3 of $B$. fragilis subsp. thetaiotaomicron. Phenotypically, the $B$. fragilis subsp. ovatus groups cannot be distinguished from each other or from the three $B$. fragilis subsp. thetaiotaomicron groups. It might also be added that we presently have an additional 30 strains which phenotypically belong to the $B$. fragilis group but have little or no homology to any of the reference strains so far used.
. It appears that, with the exception of gross cell morphology and, to a limited extent, cell wall structure, there are no phenotypic characteristics that consistently correlate with homology data within the various groups of organisms that we have investigated. However, we have found correlations that are specific for a given group. Nucleic acid homology data can serve as a basis for the interpretation of phenotypic properties. For example, if one were to obtain a number of strains having a certain level of homology with each other, phenotypic traits common to this group could then be selected that would identify organisms belonging to the group.

It appears to me that any meaningful system of taxonomy at the level of lower taxa must be 


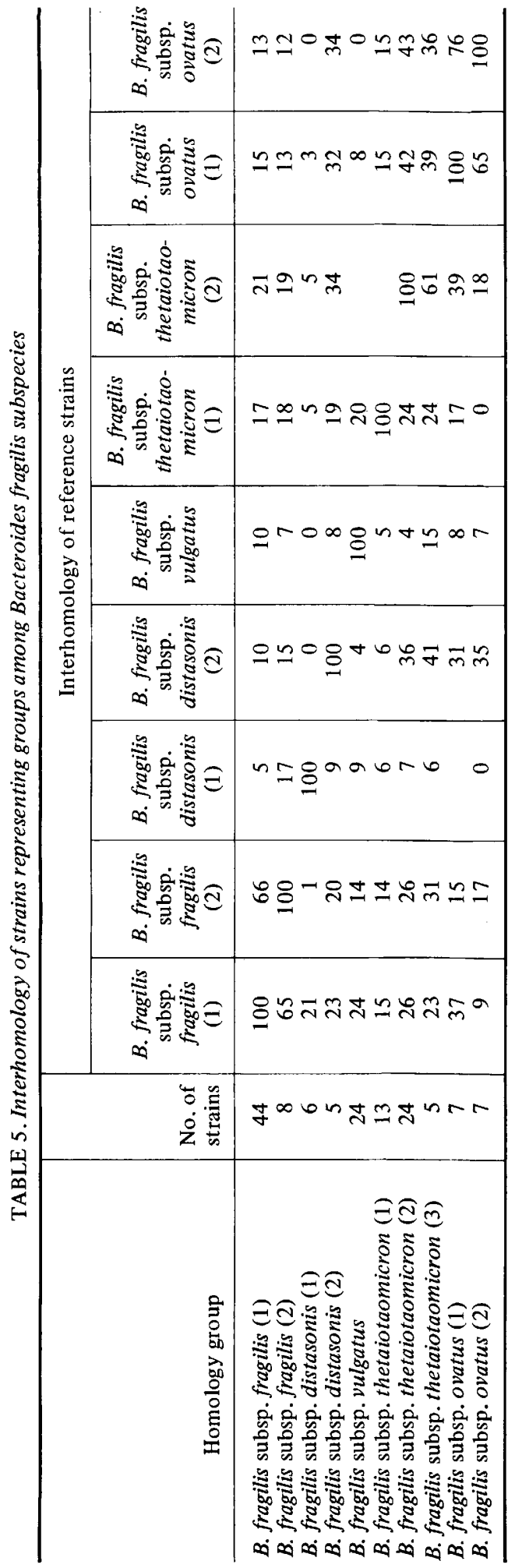

based on nucleic-acid homologies. Depicted in Fig. 4 is a proposal for consideration which would define varieties, subspecies, and species on the basis of DNA homology. This proposal is in keeping with a genetic definition of a species as discussed by Marmur et al. (13). The term genospecies, as proposed by Ravin (17), is used to differentiate these groups from those that have been phenotypically defined. Although the groupings are somewhat arbitrary, they do represent groupings that are usually observed in homology studies and from a practical standpoint will probably result in the lumping as often as in the splitting of phenotypically defined taxa.

The geno-varieties would include organisms having high homology with each other, whose DNA forms heteroduplexes having thermal stabilities similar to homologous duplexes, but which can still be separated into groups having specific phenotypic expressions. Examples are the groups based on cell wall sugar patterns and antigenic composition in $P$. acnes and $P$. avidum, and those based on patterns of susceptibility to specific phages, differences in toxin production, and so on.

The geno-subspecies would be those strains that have 60 to $70 \%$ homology with organisms in the high homology (geno variety) group. Heteroduplexes between DNA from these organisms and DNA from those in the geno-variety groups would have $\Delta T_{m}$ (e) values of 7 to $9 \mathrm{C}$. There may be some overlap in the extent of homology between the two groups, but the $\Delta T_{m}$ (e) values should enable strains to be assigned to the correct group (Fig. 3). What practical significance the geno-subspecies may

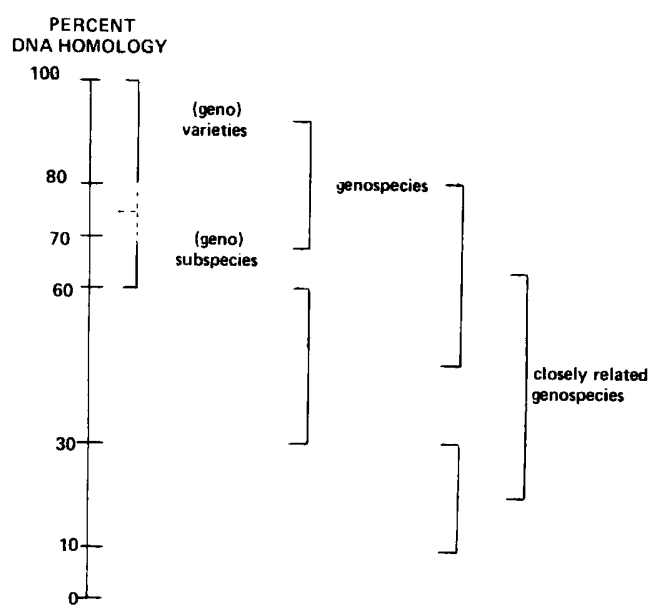

FIG. 4. Proposed taxonomic groupings based upon DNA homology data. 
have is not clear. We have observed these subgroups within phenotypically defined Fusobacterium necrophorum, $F$. nucleatum, Bacteroides fragilis subsp. fragilis, $B$. fragilis subsp. thetaiotaomicron, and $B$. fragilis subsp. ovatus. So far we have found no phenotypic traits that delineate them from strains in the geno-variety homology range, although preliminary phage typing results (T. D. Wilkins, personal communications) indicate host-range specificity within some of these groups.

There is gradation in homology levels from 50 to about $20 \%$. These I have designated as separate, but closely related, geno-species. It is important to note that interspecies transformation is usually between species with interspecies homologies within this range $(5,8,14)$.

Nucleic-acid homology studies provide a common base for establishing bacterial groups, which does not depend upon the interpretation of specific phenotypic tests. However, once these groups are established, it will be important to select phenotypic tests by which organisms in these groups can be easily and rapidly identified, without the necessity for lengthy homology investigations.

\section{ACKNOWLEDGMENTS}

The technical assistance of Habiba Najafi and Barbara Francis is gratefully acknowledged. The author is indebted to C. S. Cummins, L. V. Holdeman, and W. E. C. Moore for unpublished data and discussion of the manuscript.

This work was supported by Public Health Service grant GM-14604 from the National Institute of General Medical Sciences.

\section{REPRINT REQUESTS}

Address requests for reprints to: Dr. John L. Johnson, Anaerobe Laboratory, Virginia Polytechnic Institute and State University, Blacksburg, Virginia 24061.

\section{LITERATURE CITED}

1. Anderson, R. S., and E. J. Ordal. 1972. Deoxyribonucleic acid relationships among marine vibrios. J. Bacteriol. 109:696-706.

2. Breed, R. S., E. G. D. Murray, and N. R. Smith. 1957. Bergey's manual of determinative bacteriology, 7 th ed. Williams \& Wilkins Co., Baltimore.

3. Brenner, D. J., and D. B. Cowie. 1968. Thermal stability of Escherichia coli-Salmonella typhimurium deoxyribonucleic acid duplexes. J. Bacteriol. 95:2258-2262.

4. Cummins, C. S., and J. L. Johnson. 1971. Taxonomy of the clostridia: wall composition and DNA homologies in Clostridium butyricum and other butyric acid-producing clostridia. J. Gen. Microbiol. 67:33-46.
5. Dubnau, D., I. Smith, P. Morell, and J. Marmur. 1965. Gene conservation in Bacillus species. I. Conserved genetic and nucleic acid base sequence homologies. Proc. Nat. Acad. Sci. U. S. A. 54:491-498.

6. Holdeman, L. V., and W. E. C. Moore. 1972. Anaerobe laboratory manual. Virginia Polytechnic Institute and State University, Blacksburg, Va.

7. Johnson, J. L., R. S. Anderson, and E. J. Ordal. 1970. Nucleic acid homologies among oxidasenegative Moraxella species. J. Bacteriol. $101: 568-573$

8. Johnson, J. L., and C. S. Cummins. 1972. Cell wall composition and deoxyribonucleic acid similarities among the anaerobic coryneforms, classical propionibacteria, and strains of Arachnia propionica. J. Bacteriol. 109:1047-1066.

9. Johnson, J. L., and E. J. Ordal. 1968. Deoxyribonucleic acid homology in bacterial taxonomy: effect of incubation temperature on reaction specificity. J. Bacteriol. 95:893-900.

10. Juni, E. 1972. Interspecies transformation of Acinetobacter: genetic evidence for a ubiquitous genus. J. Bacteriol. 112:917-931.

11. Kingsbury, D. T., G. R. Fanning, K. E. Johnson, and D. J. Brenner. 1969. Thermal stability of interspecies Neisseria DNA duplexes. J. Gen. Microbiol. 55:201-208.

12. McCarthy, B. J., and E. T. Bolton. 1963. An approach to the measurement of genetic relatedness among organisms. Proc. Nat. Acad. Sci. U. S. A. 50:156-164.

13. Marmur, J., S. Falkow, and M. Mandel. 1963. New approaches to bacterial taxonomy. Annu. Rev. Microbiol. 17:329-372.

14. Moore, W. E. C., L. V. Holdeman, and C. S. Cummins. 1968. Objection: Corynebacterium acnes is not the sole legitimate anaerobic species of Corynebacterium. Int. J. Syst. Bacteriol. 18:273-274.

15. Nasser, D., G. Henderson, and E. W. Nester. 1969. Regulated enzymes of aromatic amino acid synthesis: control, isozymic nature, and aggregation in Bacillus subtilis and Bacillus licheniformis. J. Bacteriol. 98:44-50.

16. Prévot, A. R., A. Turpin, and P. Kaiser. 1967. Les bactéries anaérobies. Dunod, Paris.

17. Ravin, A. W. 1963. Experimental approaches to the study of bacterial phylogeny. Amer. Natur. 97:307-318.

18. Reid, J. D., and M. A. Joya. 1969. A study of the morphologic and biochemical characteristics of certain anaerobic corynebacteria. Int. J. Syst. Bacteriol. 19:273-280.

19. Voss, J. G. 1970. Differentiation of two groups of Corynebacterium acnes. J. Bacteriol. 101:392-397.

20. Zierdt, C. H. 1970. Synonymy of species of Corynebacterium: priority of $C$. acnes. Int. J. Syst. Bacteriol. 20:23-24.

21. Zierdt, C. H., C. Webster, and W. S. Rude. 1968. Study of the anaerobic corynebacteria. Int. J. Syst. Bacteriol. 18:33-47. 